\title{
THE PERSISTENCE OF
} INDICATORS AND PATHOGENS IN WASTEWATER BIOSOLIDSAMENDED SOIL

\section{Tanushree Parsai}

Indian Institute of Technology

Delhi, India

\section{Mark Weir}

The Ohio State University - College of Public Health

Columbus, United States

\section{Austin Miller}

Temple University

Philadelphia, United States

\section{Patrick Gurian}

Drexel University

Philadelphia, United States

\section{Arun Kumar}

Indian Institute of Technology

Delhi, India 


\section{Copyright:}

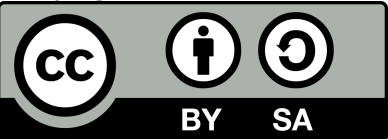

This publication is available in Open Access under the Attribution-ShareAlike 3.0 IGO (CC-BY-SA 3.0 IGO) license (http://creativecommons.org/licenses/by-sa/3.0/igo). By using the content of this publication, the users accept to be bound by the terms of use of the UNESCO Open Access Repository (http://www.unesco.org/openaccess/terms-use-ccbysa-en).

\section{Disclaimer:}

The designations employed and the presentation of material throughout this publication do not imply the expression of any opinion whatsoever on the part of UNESCO concerning the legal status of any country, territory, city or area or of its authorities, or concerning the delimitation of its frontiers or boundaries. The ideas and opinions expressed in this publication are those of the authors; they are not necessarily those of UNESCO and do not commit the Organization.

\section{Citation:}

Parsai, T., Wier, M.H., Miller, A., Gurian, P.L. and Kumar, A. 2018. The Persistence of Pathogens in Biosolidsamended Soil: Knowns, Unknowns and Future Directions. In: J.B. Rose and B. Jiménez-Cisneros, (eds) Global Water Pathogens Project, http://www.waterpathogens.org (M. Yates (eds) Part 4 Management of Risk from Excreta and Wastewater) http://www.waterpathogens.org/book/persistence-of-pathogens-inbiosolids Michigan State University, E. Lansing, MI, UNESCO. https://doi.org/10.14321/waterpathogens.52

Acknowledgements: K.R.L. Young, Project Design editor; Website Design: Agroknow (http://www.agroknow.com)

Last published: December 10, 2018 


\section{Summary}

Nutrient rich -organic residuals from wastewater treatment, also known as "biosolids", are widely used as soil conditioner and fertilizer for plant growth. These biosolids contain enteric pathogens, such as viruses, bacteria, fungi and protozoa (i.e., biosolids-associated pathogens, hereafter) which may pose risks to human during land application of biosolids. This chapter aims to summarize best data for decay of biosolids-associated pathogens in biosolids-amended soil from field -related studies for comparing their decay patterns. This type of information is currently not available easily.

Scientific publications and field reports were reviewed to obtain information on: (1) persistence of biosolidsassociated pathogens in soil after land application of biosolids (expressed in terms of T90 value, i.e., time required for $90 \%$ reduction of microorganisms) and (2) factors affecting their survival in soil. A literature review of studies indicated that most of the studies have focused on understanding fate of biosolids-associated bacteria in soil. However, very few studies are available which focus on obtaining information of fate of viruses, helminths and protozoa in biosolids-amended soil.

Overall, there is a need for conducting more field studies for determining T90 values for different pathogens in biosolids-amended soil. Following knowledge gaps were identified: (i) Lack of information on combined effect of different factors on pathogen survival, (ii) Lack of information on decay patterns of viruses, helminths, protozoa in biosolids-amended soil under field conditions.

\subsection{Introduction}

This chapter aims to summarize best data for decay of pathogens, such as bacteria, viruses, protozoa, helminths, in biosolids-amended soil using field -related studies for comparing their decay patterns. These groups of pathogens have been mentioned in the Global Water Pathogen Project (GWPP, 2018) and are principle pathogens- of- concern in biosolids (Pepper et al., 2006). The compilation of information will be useful in policy making for application of biosolids to soil.

Nutrient rich -organic residuals from wastewater treatment, also known as "biosolids", are widely used as soil conditioner and fertilizer for plant growth. These biosolids contain enteric pathogens which can spread diseases include viruses, bacteria, and protozoa (Lewis et al., 2003; Gerba and Smith, 2005; Lu et al., 2012). These biosolids might improve soil properties but introduce pathogens in soil (Pourcher et al., 2007). Land application of biosolids introduces enteric pathogens which are difficult to inactivate (Sidhu and Toze, 2009). Pathogens, present in biosolids (i.e., biosolids-associated pathogens; BAPs) might pose health risk (Eisenberg et al., 2008) through different exposure pathways (Figure 1). Land applied sludge needs proper treatment for removing pathogens before it can be applied on land. Levels of treatment required for different types of biosolids depend on pathogen concentration in biosolids and final allowable values of BAPs in soil after land application activities. For example, the USEPA Class A and Class B biosolids limits need to be followed before applying to land in the USA. Similarly, EPA Victoria has classified biosolids as Contaminant grade and Treatment grade and has different management rules for land application (EPA Australia). There are around 150 microbial pathogens which have been identified from all animal species that can be transmitted and, can be harmful for human (USEPA, 1998).

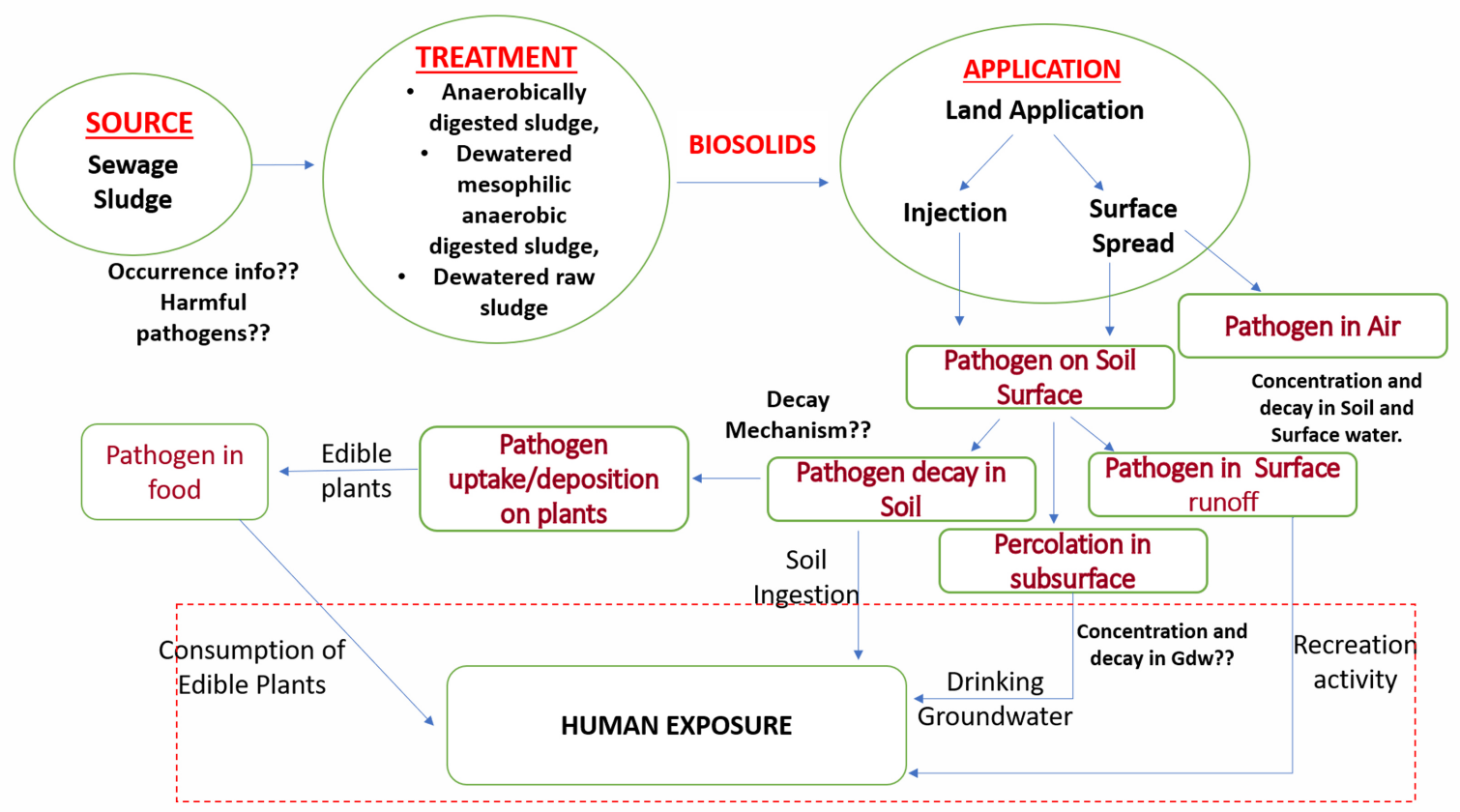

Figure 1. Schematic of possible interlinking of pathogens in sludge to biosolids treatment methods, land application activities and human exposure pathways Gdw-groundwater (Gerba and Smith, 2005; Gale, 2005; Eisenberg et al., 2008; Gurian et al., 2012; Lu et al., 2012) 
Various studies have focused on determining concentrations of bacteria, viruses, protozoa in soil and surface and groundwater to under potential health risk. To understand decay behaviours of different BAPs in biosolids-amended soil, information related to decay of indicator microorganisms and pathogens in biosolids and biosolids-amended soil was compiled from different published field studies. Different keywords were entered in the Science Direct database and studies/papers relevant to our present context, i.e., decay of pathogen in biosolids- amended soil in field-based studies was compiled. This approach ensured the consideration of all relevant published papers from the database. Figure 2 shows keywords searched in science direct and number of studies obtained. Numbers of studies, found after entering different keywords, are presented in Figure 2. It also indicates number of those studies which were found to be relevant to our area of focus, i.e., "pathogen decay in biosolids amended soil". It also includes some studies which were selected from the database of "Google Scholar". Laboratory studies have been conducted to understand decay patterns of pathogens in mixtures of biosolids and soil, but there have been very few field-based studies. Data of field-based studies were compiled. Findings of laboratory studies were also included for those pathogens where not enough data on field studies was available.

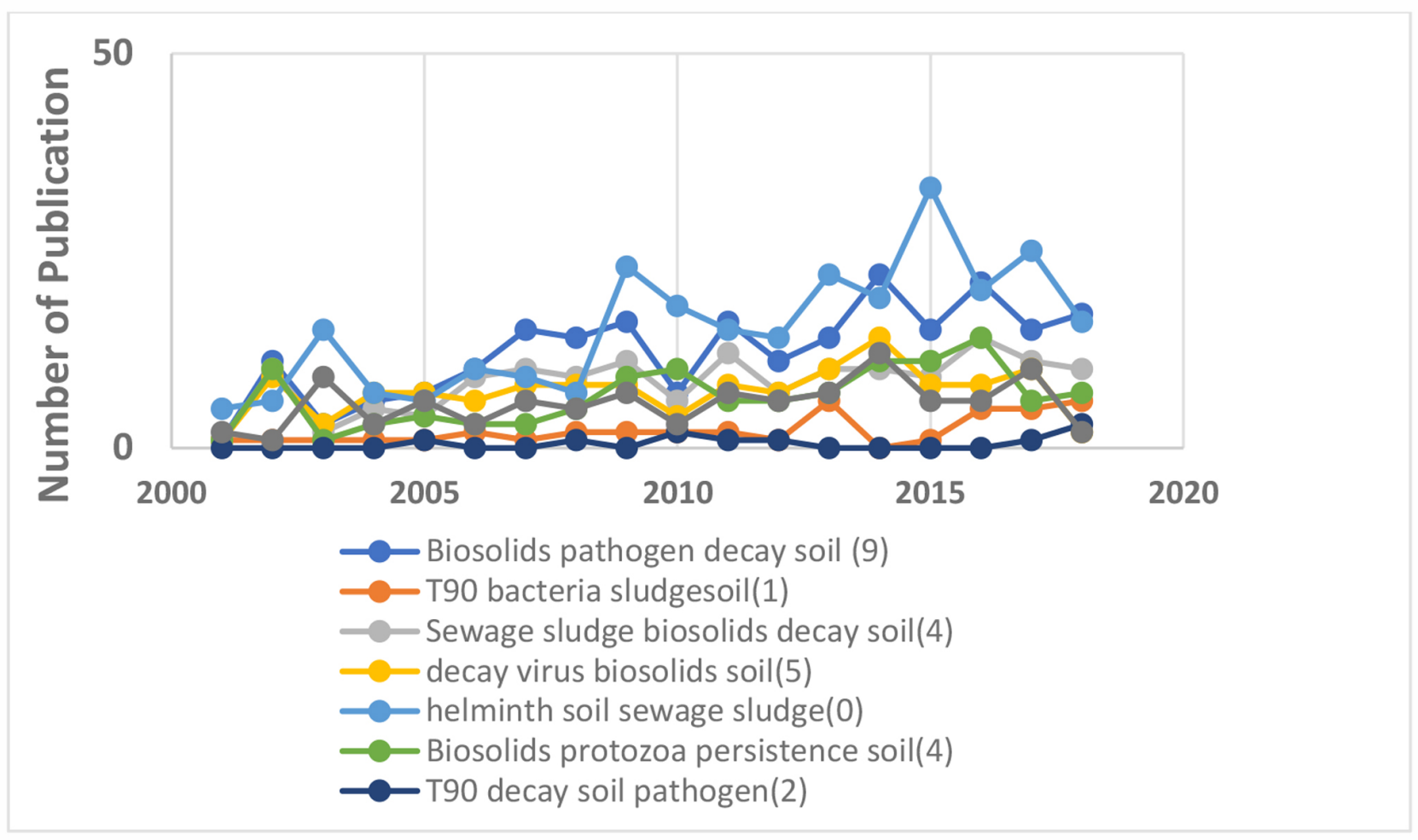

Figure 2. Trend of published scientific articles over time in various areas-related to biosolids-amended soils Numbers in bracket represent studies which satisfied our area of focus "pathogen decay in soil amended with biosolids". Data obtained from the Science Direct database on June 2nd, 2018 using keywords mentioned in legends of this figure.

Information on persistence of pathogen in biosolids- amended soil, expressed as T90 (i.e., time required for $90 \%$ reduction of pathogen) was compiled along with experimental conditions (example: soil type, temperature and moisture, method of application of biosolids, etc.). T90 values reported in published studies were used as-is. Studies where T90 values were not reported, "GetData" software was used to extract points from time versus concentration plots. The extracted $\mathrm{x}$ and $\mathrm{y}$ values were exported to an Excel 2016 spreadsheet for plotting a graph and estimating T90 values. Results of concentration values versus time were plotted on a base 10 semi-logarithmic graph and a linear regression was performed on the transformed data. The first order decay model (i.e., model $\# 1: \log (\mathrm{C} / \mathrm{C} 0)=(-) \mathrm{kt}$ ) was used where $\mathrm{C}$ is the concentration at a given time point, $\mathrm{C} 0$ is the initial concentration, $\mathrm{k}$ is the decay rate, and $(\mathrm{t})$ is time.
This approach was used for those studies where no time-lag (i.e., termed as $\lambda$, hereafter) was observed during decay of pathogens. For studies, where time-lag in decay of pathogen was reported, the $\mathrm{X}$-axis parameter (i.e., exposure duration $(\mathrm{t})$ ) was transformed to $(\mathrm{t}-\lambda)($ model $\# 2: \log (\mathrm{C} / \mathrm{C} 0)=(-\mathrm{k}(\mathrm{t}-\lambda)))$. The slope value was taken as the inactivation rate constant and the inverse of slope was estimated to be the T90 value $(\log (0.1)=-$ $k t^{*}$ where $t^{*}=t$ if no time-lag in decay of pathogens and $t^{*}=(t-\lambda)$ if time delay happens in pathogen decay. A summary of numbers of published studies, used in directly obtaining or calculating values of T90 of decay of bacteria, viruses, helminths and protozoa in biosolids- amended soil is presented in Table 1. 
Table 1. Summary of numbers of published studies, used in directly obtaining or calculating values of $T_{90}$ of decay of bacteria, viruses, helminths and protozoa in biosolids- amended soil

\begin{tabular}{|c|c|c|c|c|c|c|c|c|}
\hline & \multicolumn{2}{|c|}{ Bacteria } & \multicolumn{2}{|c|}{ Virus } & \multicolumn{2}{|c|}{ Helminths } & \multicolumn{2}{|c|}{ Protozoa } \\
\hline & $\begin{array}{c}\text { Field } \\
\text { Studies }\end{array}$ & $\begin{array}{c}\text { Lab }^{\mathrm{a}} \\
\text { Studies }\end{array}$ & $\begin{array}{c}\text { Field } \\
\text { Studies }\end{array}$ & $\begin{array}{c}\text { Lab } \\
\text { Studies }\end{array}$ & $\begin{array}{c}\text { Field } \\
\text { Studies }\end{array}$ & $\begin{array}{c}\text { Lab } \\
\text { Studies }\end{array}$ & $\begin{array}{c}\text { Field } \\
\text { Studies }\end{array}$ & $\begin{array}{c}\text { Lab } \\
\text { Studies }\end{array}$ \\
\hline $\begin{array}{l}\text { Number of } \\
\text { Published } \\
\text { Useful for }\end{array}$ & 12 & 4 & 1 & 2 & 1 & 1 & 1 & 1 \\
\hline Getting T90 & & & & & & & & \\
\hline T90 Given & 8 & 4 & 1 & 2 & 1 & 1 & 1 & 1 \\
\hline $\begin{array}{l}\text { T90 Calculated } \\
(\text { Model 1) }\end{array}$ & 4 & 0 & 0 & 0 & 0 & 0 & 0 & 0 \\
\hline $\begin{array}{l}\text { T90 Calculated } \\
\text { (Model 2) }^{\mathbf{C}}\end{array}$ & 0 & 0 & 0 & 0 & 0 & 0 & 0 & 0 \\
\hline
\end{tabular}

${ }^{\mathrm{a}} \mathrm{iabW}=\mathrm{lab}{ }^{\circ} \mathrm{rat}^{\circ} \mathrm{ry} ;{ }^{\mathrm{b}} \operatorname{Model} \# 1:\{\log (\mathrm{C} / \mathrm{C})=(-) \mathrm{kt}\} ;{ }^{\mathrm{c}} \operatorname{Model} \# 2:\left\{\log \left(\mathrm{C} / \mathrm{C}_{0}\right)=(-\mathrm{k}(\mathrm{t}-\lambda))\right\}$

Following sections presents a compilation of $\mathrm{T}_{90}$ values of bacterial pathogens and indicators, viruses, protozoa and helminths in biosolids-amended soils and discuss factors affecting their decay patterns. The last section documents identified knowledge gaps and suggest possible actions for filling these knowledge gaps.

\subsection{Persistence of bacterial pathogens and indicator bacteria in biosolids- amended soil}

This section documents $T_{90}$ values of bacterial pathogens and indicators in biosolids-amended soil and studies effect of soil temperature, soil moisture and soil type on persistence (i.e., T90 values) under field- and laboratoryconditions. Information on experimental conditions of different laboratory- and field-based studies and decay of bacterial indicators and pathogens (i.e., Faecal coliforms,

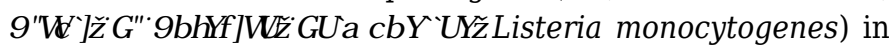
biosolids-amended soils are presented in Tables 2 and 3, respectively. These tables present information on biosolids type used and application method, climatic region, experimental conditions (soil type, temperature and moisture, biotic stress, $\mathrm{T}_{90}$ value and decay rate). Followingections discuss effects of significant factors which affect decay of microorganisms in biosolids-amended soil.

Table 2. Summary of findings of field-based studies on persistence of bacterial indicators and bacterial pathogens in biosolids- amended soil

\begin{tabular}{|c|c|c|c|c|c|c|}
\hline $\begin{array}{l}\text { Country/ } \\
\text { Climatic } \\
\text { Region }\end{array}$ & $\begin{array}{l}\text { Method of } \\
\text { Application }\end{array}$ & $\begin{array}{l}\text { Experimental } \\
\text { Conditions }\end{array}$ & $\begin{array}{c}\text { Indicator } \\
\text { Microorganisms/Pathogen } \\
\text { Studied }\end{array}$ & $\begin{array}{c}\text { Study Period } \\
\text { (Days) }\end{array}$ & $\begin{array}{c}\text { T90 } \\
\text { (in } \\
\text { Days) }\end{array}$ & References \\
\hline
\end{tabular}

\begin{tabular}{|c|c|c|c|c|c|c|}
\hline \multicolumn{7}{|c|}{ Anaerobically-digested Sludge } \\
\hline \multirow{3}{*}{$\begin{array}{l}\text { Australia, } \\
\text { Sub tropical }\end{array}$} & $\begin{array}{l}\text { Injection } \\
\text { method }\end{array}$ & $\begin{array}{l}\text { Sandy soil; soil } \\
\text { temperature = }\end{array}$ & Faecal coliforms & 259 & $28^{a}$ & \multirow{3}{*}{ Gibbs et al., } \\
\hline & (depth=7 & 12 to $30^{\circ} \mathrm{C}$ & Faecal streptococci & 259 & $84^{\mathrm{a}}$ & \\
\hline & $\begin{array}{l}\mathrm{cm}) \text {; rate }= \\
10 \text { t/ha }\end{array}$ & $\begin{array}{l}\text { soil moisture = } \\
1 \text { to } 22 \%\end{array}$ & & & & \\
\hline
\end{tabular}




\begin{tabular}{llcccc}
\hline $\begin{array}{l}\text { Country/ } \\
\text { Climatic } \\
\text { Region }\end{array}$ & $\begin{array}{c}\text { Method of } \\
\text { Application }\end{array}$ & $\begin{array}{c}\text { Experimental } \\
\text { Conditions }\end{array}$ & $\begin{array}{c}\text { Indicator } \\
\text { Microorganisms/Pathogen } \\
\text { Studied }\end{array}$ & $\begin{array}{c}\text { Study Period } \\
\text { (Days) }\end{array}$ & $\begin{array}{c}\text { Tgo } \\
\text { (in } \\
\text { Days) }\end{array}$ \\
\hline
\end{tabular}

\section{Anaerobically-digested Sludge}

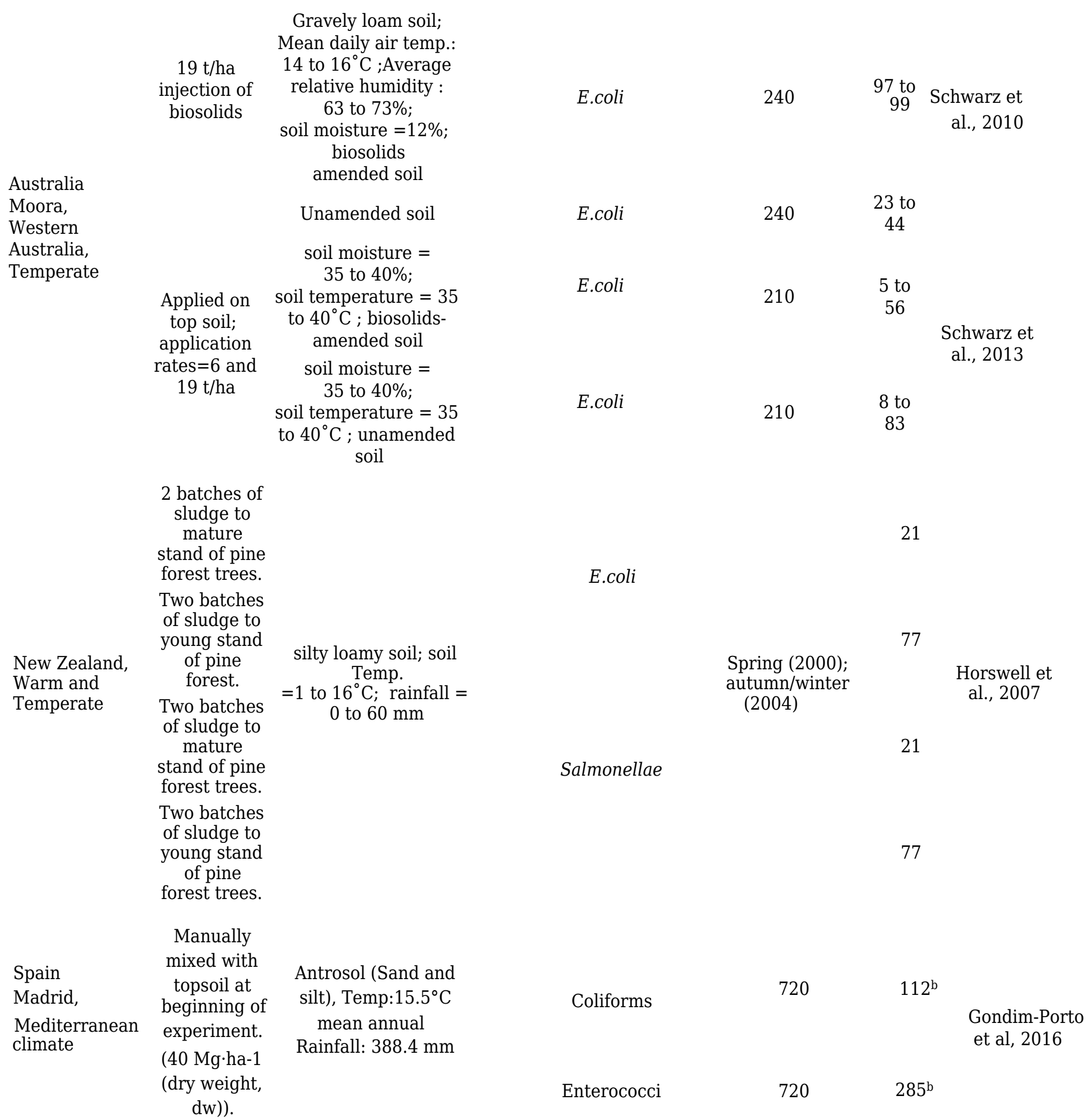




\begin{tabular}{llccccc}
\hline $\begin{array}{l}\text { Country/ } \\
\text { Climatic } \\
\text { Region }\end{array}$ & $\begin{array}{c}\text { Method of } \\
\text { Application }\end{array}$ & $\begin{array}{c}\text { Experimental } \\
\text { Conditions }\end{array}$ & $\begin{array}{c}\text { Indicator } \\
\text { Microorganisms/Pathogen } \\
\text { Studied }\end{array}$ & $\begin{array}{c}\text { Study Period } \\
\text { (Days) }\end{array}$ & $\begin{array}{c}\text { T90 } \\
\text { (in } \\
\text { Days) }\end{array}$ & $\begin{array}{c}\text { References } \\
\text { (Dans }\end{array}$ \\
\hline
\end{tabular}

\section{Anaerobically-digested Sludge}

\section{Injection method \\ Surface} (0 to $50 \mathrm{~cm})$; Subsurface (50 to 250 $\mathrm{cm}$ )

USA, Soil cores

Tropical from surface and subsurface, Soil Spring season moisture: (February, 1990- to 10.5\% May,1990) Soil temperature: $9^{\circ} \mathrm{C}$

USA

Arizona, Desert Injection climate method
Fall season

(September,1989-April 1990)
Clay loam soil; soil moisture $=5 \%$; rewetting to $60 \%$ moisture.

Faecal coliforms

Faecal coliforms

120

Pepper et al., 1993

120

$113^{a}$

Salmonellae

161 and 210
Zaleski et al. 2005

\section{Aerobic Digested Sludge}

Spain
Madrid,
Mediterranean
climate

Manually mixed with topsoil at beginning of experiment. (40 Mg.ha-1 (dry weight,

Antrosol (Sand and silt), Temp: $15.5^{\circ} \mathrm{C}$ mean annual

Rainfall: $388.4 \mathrm{~mm}$ $\mathrm{dw})$ ).
Coliforms

enterococci
720

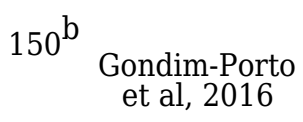

720

$230^{\mathrm{b}}$

\section{Mechanically-dewatered Biosolids}

$\begin{array}{lc} & 5 \text { different } \\ & \text { field sites } \\ & \text { (Sandy loam } \\ \text { Australia } & \text { top soil; clay } \\ \text { Sydney, } & \text { subsoil) } \\ \text { Temperate } & \text { (rate=10 } \\ \text { climate } & \text { t/ha; } 30 \\ & \text { t/ha); } 3 \\ & \text { times }\end{array}$

\section{Surface}

Application

Surface incorporation

$$
\text { Surface }
$$

$$
\text { Application }
$$

Surface incorporation

$$
\begin{gathered}
\text { E. coli } \\
\text { Salmonella } \\
\text { C. perfringens }
\end{gathered}
$$$$
10^{\mathrm{b}}
$$$$
8^{\mathrm{b}}
$$$$
\text { Spring and }
$$$$
\text { summer for }
$$$$
357
$$$$
9^{b}
$$$$
10^{\mathrm{b}}
$$$$
\text { Surface }
$$$$
\text { Application }
$$

$$
42^{\mathrm{b}}
$$$$
34^{\mathrm{b}}
$$ 


\begin{tabular}{|c|c|c|c|c|c|c|}
\hline $\begin{array}{l}\text { Country/ } \\
\text { Climatic } \\
\text { Region }\end{array}$ & $\begin{array}{c}\text { Method of } \\
\text { Application }\end{array}$ & $\begin{array}{c}\text { Experimental } \\
\text { Conditions }\end{array}$ & $\begin{array}{c}\text { Indicator } \\
\text { Microorganisms/Pathogen } \\
\text { Studied }\end{array}$ & $\begin{array}{l}\text { Study Period } \\
\text { (Days) }\end{array}$ & $\begin{array}{c}\text { T90 } \\
\text { (in } \\
\text { Days) }\end{array}$ & References \\
\hline
\end{tabular}

Dewatered Anaerobically Digested Sludge (DMAD)

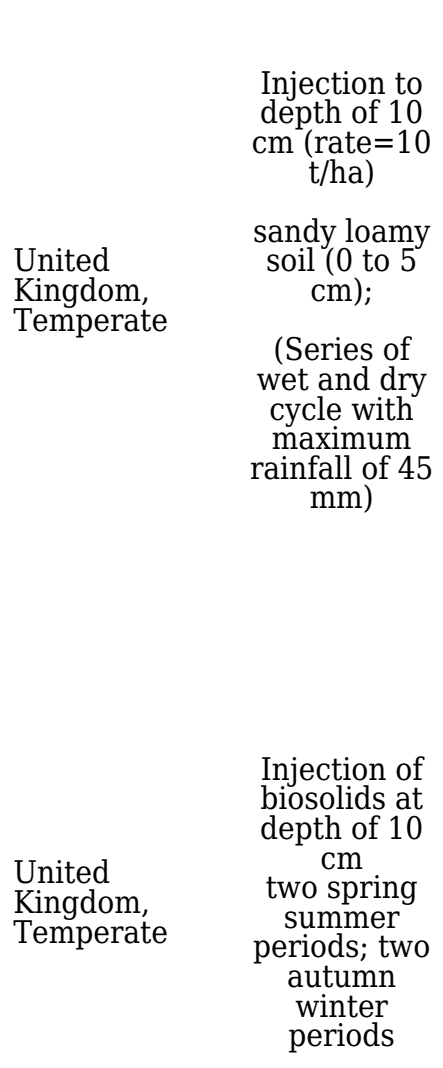

Dewatered Raw Sludge (DRAW)

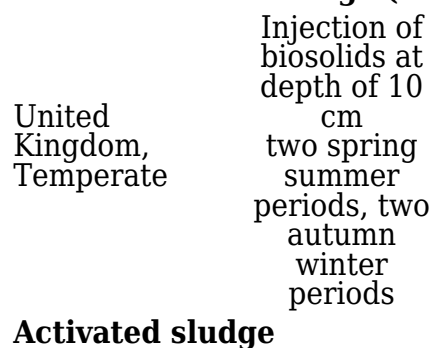

France,

Temperate

Open slot injection, 80 $\mathrm{m}^{3} / \mathrm{ha}$
Trial 1

(June 2001):

$20{ }^{\circ} \mathrm{C}$

\section{E.coli}

89

$35^{\mathrm{b}}$

Trial 2

0.7 to $13^{\circ} \mathrm{C}$

Mean soil moisture

$: 12.5$ to $21 \%$

(Trial 1:

June-August)

Mean soil moisture

:19 to 23\%

(Trial 2:

E.coli

119

$33^{\mathrm{b}}$

October-February)

Mean soil moisture

:12.5to $21 \%$

(Trials 3:

April-July)

E. coli

84

$32^{\mathrm{b}}$

Lang et al. 2003

Clay loam

Clay

two spring summer periods, two autumn winter periods

Clay loam

Clay

Clay loam

Clay

E. coli

119

$46^{\mathrm{b}}$

E. coli

91

$28^{\mathrm{b}}$

E.coli

316

53

E.coli

316

26

E.coli O157:H7

316

11

S. enterica

316

S. enterica

316

Listeria monocytogenes

316

Listeria monocytogenes

S. enterica

316

Clay

Clay loam

Clay

Clay loam

Clay

S. enterica

316

E.coli

E.coli

316

316

Listeria monocytogenes

316

Listeria monocytogenes

316

E. coli

60

Enterococci

60

60

C. perfringens
15.1 and $4.58^{\circ} \mathrm{C}$,

Sandy soil,

Temperature:

Moisture content:
20

Cass, 2009

$$
19
$$

Cass,2009

40

37

Pourcher et al.,2007

NA

\section{Composted Sludge with Green Waste (CPT)}

\begin{tabular}{|c|c|}
\hline & $\begin{array}{l}\text { Injection to } \\
\text { depth of } 10\end{array}$ \\
\hline ited & $\mathrm{cm} ;$ rate $=10$ \\
\hline Kingdom, & t/ha) \\
\hline Temperate & sandy loamy \\
\hline & $\begin{array}{c}\text { soil } \\
(0 \text { to } 5 \mathrm{~cm})\end{array}$ \\
\hline & $\begin{array}{c}\text { rainfall }=45 \\
\mathrm{~mm}\end{array}$ \\
\hline
\end{tabular}

$$
\text { E.coli }
$$

Trial 2:

0.7 to $13^{\circ} \mathrm{C}$

Trial 1: $20^{\circ} \mathrm{C}$

E.coli
119 


\begin{tabular}{llcccc}
\hline $\begin{array}{l}\text { Country/ } \\
\text { Climatic } \\
\text { Region }\end{array}$ & $\begin{array}{c}\text { Method of } \\
\text { Application }\end{array}$ & $\begin{array}{c}\text { Experimental } \\
\text { Conditions }\end{array}$ & $\begin{array}{c}\text { Indicator } \\
\text { Microorganisms/Pathogen } \\
\text { Studied }\end{array}$ & $\begin{array}{c}\text { Study Period } \\
\text { (Days) }\end{array}$ & $\begin{array}{c}\text { Tgo } \\
\text { (in } \\
\text { Days) }\end{array}$ \\
\hline
\end{tabular}

Thermally Dried Digested Product (TDD)

\begin{tabular}{|c|c|c|c|c|c|c|}
\hline & $\begin{array}{c}\text { Injection to } \\
\text { depth of } 10 \\
\mathrm{~cm} ; \text { rate }=10\end{array}$ & Trial $1: 20^{\circ} \mathrm{C}$ & E.coli & 89 & $71^{b}$ & \\
\hline Kingdom, & t/ha sandy & & & & & Lang et al., \\
\hline Temperate & $\begin{array}{c}\text { loamy soil } \\
\text { (0 to } 5 \mathrm{~cm}) \\
\text { rainfall }=45 \\
\mathrm{~mm}\end{array}$ & $\begin{array}{c}\text { Trial 2: } \\
0.7 \text { to } 13^{\circ} \mathrm{C}\end{array}$ & E.coli & 119 & $47^{\mathrm{b}}$ & \\
\hline
\end{tabular}

NA: Not available; NE: Not estimated; NR: Not reported; ${ }^{a}$ Time after which bacteria reaches nondetectable levels (used if $\mathrm{T}_{90}$ is unavailable); ${ }^{\mathrm{b}} \mathrm{T}_{90}$ values calculated from model described in methodology

Table 3. Summary of findings of laboratory-based studies on persistence of bacterial indicators and bacterial pathogens in biosolids- amended soil

\begin{tabular}{lccccc}
\hline $\begin{array}{l}\text { Country/ } \\
\text { Climatic }\end{array}$ & $\begin{array}{c}\text { Method of } \\
\text { Application }\end{array}$ & $\begin{array}{c}\text { Experimental } \\
\text { Conditions }\end{array}$ & $\begin{array}{c}\text { Indicators or } \\
\text { Pathogen Studied }\end{array}$ & $\begin{array}{c}\text { Study Period } \\
\text { (Days) }\end{array}$ & $\begin{array}{c}\text { T90 } \\
\text { (Days) }\end{array}$ \\
\hline
\end{tabular}

\section{Anaerobically-digested Sludge}

\begin{tabular}{|c|c|c|c|c|c|c|}
\hline $\begin{array}{l}\text { Botswana, } \\
\text { Semi Arid }\end{array}$ & $\begin{array}{c}\text { Soil- sludge } \\
\text { mixture (total } \\
\text { volume }=4.1 \times \\
10^{-2} \mathrm{~m}^{3} \text { ) }\end{array}$ & $\begin{array}{l}\text { Botswana soll } \\
\text { (Vertisol, } \\
\text { luvisols and } \\
\text { arenosol); } \\
\text { temp. = } 13.6 \\
\text { to } 29.7^{\circ} \mathrm{C} \text {; total } \\
\text { rainfall }=268 \mathrm{~mm}\end{array}$ & E.coli & 90 & 90 & $\begin{array}{l}\text { Ngole et al. } \\
2006\end{array}$ \\
\hline $\begin{array}{l}\text { USA, } \\
\text { Tropical } \\
\text { climate }\end{array}$ & $\begin{array}{c}\text { Injection } \\
\text { method; Surface } \\
\text { (0 to } 50 \\
\mathrm{~cm}) ; \text { Subsurface } \\
\text { (50 to } 250 \\
\mathrm{~cm}) \text { rate=15,000 } \\
\text { gallons/acre } \\
\text { Microcosm } \\
\text { study with } \\
\text { Brazito sandy } \\
\text { soil and Prima } \\
\text { clay loam soil; }\end{array}$ & Spring season & $\begin{array}{c}\text { Faecal } \\
\text { coliforms }\end{array}$ & 120 & $113^{\mathrm{a}}$ & $\begin{array}{l}\text { Pepper et } \\
\text { al., } 1993\end{array}$ \\
\hline \multicolumn{7}{|c|}{$\begin{array}{r}\text { Dewatered, Mesophilic Anaerobically Digested (DMAD) } \\
\text { sandy and silty }\end{array}$} \\
\hline \multirow[t]{2}{*}{$\begin{array}{l}\text { United } \\
\text { Kingdom, } \\
\text { Temperate }\end{array}$} & $\begin{array}{l}\text { Soil-biosolid } \\
\text { mixture }\end{array}$ & $\begin{array}{c}\text { sandy soils; } \\
\text { air-dried soil } \\
\left(20^{\circ} \mathrm{C}\right)\end{array}$ & E.coli & 91 & 100 & \multirow[t]{2}{*}{$\begin{array}{l}\text { Lang and } \\
\text { Smith, } 2007\end{array}$} \\
\hline & & $\begin{array}{c}\text { Slity soil; } \\
\text { air-dried soil }\left(20^{\circ} \mathrm{C}\right)\end{array}$ & E.coli & 91 & 200 & \\
\hline \multicolumn{7}{|c|}{ Class B Biosolids from Municipal Wastewater Treatment Plant } \\
\hline \multirow{4}{*}{$\begin{array}{l}\text { Mississippi, } \\
\text { USA; } \\
\text { subtropical } \\
\text { humid } \\
\text { climate }\end{array}$} & \multirow{4}{*}{$\begin{array}{l}\text { Soil-biosolids } \\
\text { mixture }\end{array}$} & $\begin{array}{l}30^{\circ} \mathrm{C}(14 \mathrm{~h}) \\
20^{\circ} \mathrm{C}(10 \mathrm{~h}) \\
\text { moisture }\end{array}$ & $\begin{array}{c}\text { Salmonella } \\
\text { enterica } \\
\text { C. jejuni }\end{array}$ & $\begin{array}{l}216 \\
216\end{array}$ & $\begin{array}{l}\text { NA } \\
15^{\mathrm{b}}\end{array}$ & \multirow{4}{*}{$\begin{array}{l}\text { Roberts et } \\
\text { al., } 2016\end{array}$} \\
\hline & & $\begin{array}{l}\text { content }=25 \% \\
30^{\circ} \mathrm{C}(14 \mathrm{~h}) \\
20^{\circ} \mathrm{C}(10 \mathrm{~h})\end{array}$ & $\begin{array}{l}\text { Listeria } \\
\text { monocytogenes }\end{array}$ & 216 & $4^{b}$ & \\
\hline & & $\begin{array}{c}\text { moisture } \\
\text { content }=25 \%\end{array}$ & $\begin{array}{l}\text { Escherichia coli } \\
\text { O157:H7 }\end{array}$ & 216 & $12^{\mathrm{b}}$ & \\
\hline & & & $\begin{array}{l}\text { Clostridium } \\
\text { perfringens }\end{array}$ & 216 & $131^{b}$ & \\
\hline
\end{tabular}

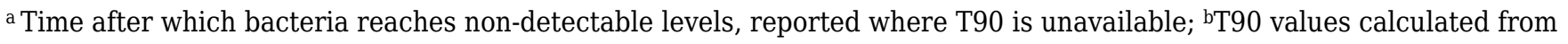
model described in methodology 


\subsection{Soil temperature and soil moisture}

This section documents effect of soil temperature on $\mathrm{T}_{90}$ values of bacterial pathogens and indicators in biosolidsamended soil and compares $\mathrm{T}_{90}$ values of E.coli of different biosolids types in soil. Studies have reported effect of variation of temperature on decay of bacterial indicator and pathogens in biosolids-amended soil. Concentrations of E.coli and Salmonellae were observed to increase in soil in temperate region (Ascot, UK) during autumn-winter (temperature range: $0.7-13^{\circ} \mathrm{C}$ ) and spring-summer (temperature range: $13-25^{\circ} \mathrm{C}$ ) because of favourable conditions of temperature and moisture for microbial growth and decline during summer due to dry conditions (Lang et al., 2007). Similarly, another study reported undetectable concentrations of faecal coliforms and Salmonellae during the summer period and high concentrations of these microorganisms under favourable conditions (Gibbs et al., 1997). Concentrations of indigenous E.coli were observed to decrease in soil amended with enhanced treated biosolids than in control soil (Lang et al., 2007). About 90\% reduction in Salmonella concentration was observed in 21 days in a mature stand of concentration was observed in 21 days in a mature stand of trees and 77 days in a young stand (closed, mature tree stand and open, young tree stand forest canopy in spring and autumn / winter) with the longest survival interval in winter ( Horswell et al. , 2007). In another study, T90 value of faecal coliform decay was observed to be 3.3 days (in summer) and 13.4 days (in winter) (Van Donsal et al., 1967). A comparison of T90 values of decay of E.coli of different biosolids in silty loam or clay loam soil in temperate region $\left(10-20^{\circ} \mathrm{C}\right)$ (Figure 3$)$ indicated that E.coli of biosolids types such as anaerobically digested sludge, mechanically dewatered biosolids or DMAD survive for shorter time period (Figure 3) than that of biosolids type, such as composted sludge, thermally dried digested biosolids or dewatered raw sludge. Overall, these observations indicate that consideration of ambient temperature during land application of biosolids is important as it can increase or decrease decay of bacterial indicator or bacterial pathogens in biosolidsamended soil. These microorganisms are likely to survive more in winter weather than in summer weather, indicating the importance of tracking their survival patterns in different seasons.

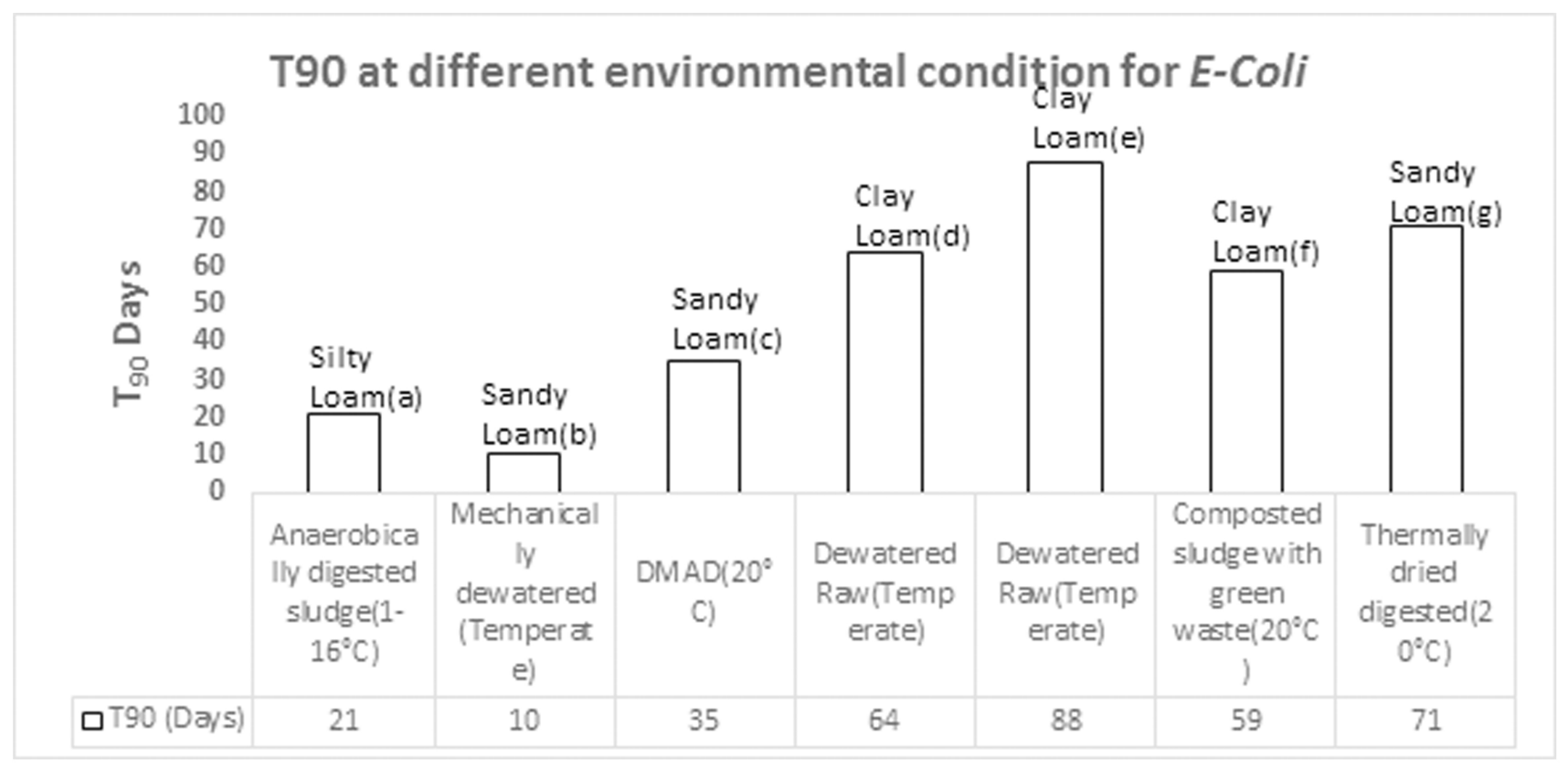

Figure 3. A comparison of $T_{90}$ values of decay of $E$. coli in different environmental conditions 
This section documents effect of soil moisture on decay of bacterial pathogens and indicators in biosolids-amended soil. Moisture content has been shown to affect survival of bacteria (Burge et al. ,1987; Ngole et al., 2006). For example, moisture content equivalent to field capacity was observed to increase number of E.coli in spring/ autumn season and accounted for variation of $11-25 \%$ in E.coli numbers (DMAD, sandy loam soil, Mean soil moisture :12.5-21\%; Lang et al., 2007). This study reported that rewetting-drying soil conditions affected decay of pathogens of enhanced -treated biosolids. They further noticed the increase in E.coli numbers for 2-3 months in soil- amended with conventionally -treated biosolids and attributed to effect of soil wetting. In this regard, some studies have also reported an increase in bacteria concentration after rain event and attributed to the effect of increased moisture content on re-colonization of bacteria (Dehydrated anaerobic digested sludge, Moisture content: 5.1-22.8\%, Temperature: $5-20^{\circ} \mathrm{C}$, silty sandy soil;Estrada et al., 2004). For example, recolonization of Salmonella and faecal coliform was observed after the rain event (Zaleski et al., 2005). Another study reported an increase in numbers of faecal coliforms and Salmonella after rainfall events (soil temperature $=12-30^{\circ} \mathrm{C}$; soil moisture $=1$ to $22 \%$, sandy soil) (Gibbs et al., 1997). In general, bacterial pathogen and indictor bacteria die more in reduced moisture content. However, some studies have reported a different trend of decay of indicator bacteria with soil moisture content (Chandler and Craven, 1980; Lang et al., 2007; Lang and Smith, 2007; Cass, 2009). For example, a UK -based study (Location: Ascot, UK) reported a greater decay of E.coli of biosolids amended in moist soil (T90 $=20$ days) than in dry soil (T90 $=100-200$ days) and attributed to the effect of competition of E.coli with other indigenous soilmicroorganisms for nutrients and moisture (DMAD, sandy loam soil; Mean soil moisture: 12.5-21\%; Table 2; Lang et al., 2007). The above mentioned discrepancies in relationship of survival of bacteria with soil moisture content from two different groups of studies (Burge et al., 1987; Ngole et al., 2006; Zaleski et al., 2005; Estrada et al., 2004; Chandler and Craven, 1980; Lang et al.,2007; Lang and Smith, 2007; Cass, 2009) indicate the need for incorporating the effect of interaction of soil moisture content with other factors on survival of bacteria under field conditions. 


\subsection{Soil Type}

This section documents effect of soil type (sand, clay and silt) and soil texture (fine versus coarse) on decay of bacterial pathogens and indicators in biosolids-amended soil. Sometimes, mixing of biosolids with soil might result in a soil environment, not conducive for bacteria growth. For example, higher rate of survival of fecal coliforms was reported in fine textured soil (i.e., Pima soil) than in coarse textured soil (i.e., Brazito soil) (Pepper et al., 1993). Studies have also reported effect of presence of clay in soil on survival of bacteria (Ngole et al., 2006; Lang and Smith, 2007). For example, survival rates of E.coli were observed to be higher in fine texture of the vertisol (with high clay content) than in luvisols and arensol (Ngole et al., 2006). In spring period, ribotype 027 spores decreased in loam soil with no change in numbers in sandy loam soil (Xu et al, 2016). In addition, the presence of organic matter in soil has also been reported to affect survival of bacterial indicator and bacterial pathogens (Sessitsch et al., 2001). Organic matter in soil aids in formation of soil aggregates where bacterial pathogens can reside and remain shielded from predators. Above observations indicate that soil type and soil characteristics (texture, presence of organic content) can influence the survival of bacteria in biosolidsamended soil.

\subsection{Biotic Stress}

This section documents effect of biotic stress (due to background microbial community) on decay of bacterial pathogens and indicators in biosolids-amended soil. Predation processes are likely to be an important pathogen inactivation mechanism in biosolids-amended soil. Predation and parasitism are considered to be one of the major factors affecting persistence (Roper and Marshall, 1978). For example, a UK study reported that both the indigenous soil and sludge microbial communities affected decay of E. coli in biosolids- amended soil (Lang et al., 2007). Decay of indicator organisms in soil has also been linked to change in biotic stress. Indigenous microbial population restricts regrowth and re-colonization of bacteria (Zaleski et al., 2005). Background E. coli., present in environment, has been shown to affect decay of enteric bacteria. For example, persistence of Salmonella was found to be affected by microbial antagonism of indigenous soil microbial community (You et al., 2006). Protozoa has been found to graze bacteria, with predation of gram negative bacteria (Rogers and Smith, 2007). For example, a reduction in $S$. typhimurium numbers was observed after addition of protozoa (Mallory et al., 1983).

\subsection{Combined effect of different environment factors on bacterial survival}

This section documents effect of interaction amongst different factors, such as soil temperature, soil moisture, soil type (sand, clay and silt), soil texture (fine versus coarse) on decay of bacterial pathogens and indicators in biosolids-amended soil. Although decay of bacteria in biosolids-amended soil depends on different factors, very few studies have studied combined effect of different factors, such as temperature, moisture content, soil type and characteristics, biotic stress (Lang et al., 2007; Cass, 2009). An UK study focused on studying combined effect of temperature and moisture content on decay of E.coli and Salmonella in biosolids-amended soil in temperate condition and reported that temperature and moisture had little effects on bacterial decay (Lang et al., 2007). Another study reported that high number of microorganisms were present at high temperature as contradictory to other studies (Temp: $15.5^{\circ} \mathrm{C}$, mean annual rainfall: $388.4 \mathrm{~mm}$, Table 2; Gondim-Porto et al., 2017) and attributed to the combined effects of other factors, such as solar radiation, type of soil in mediterranean climate, etc. Effects of type of biosolids, time from amendment and some other physical properties (i.e., water content of the samples, daily average temperature and air humidity) were found to have $44.5 \%$ variation in bacterial population with dose and time being the major affecting factors. More field studies, similar to those of Lang et al. (2007) and Cass (2009), need to be conducted to identify combined effect of different factors on survival of bacteria in field-related conditions.

\subsection{Persistence of viral pathogens in biosolids-amended soil}

This section documents persistence of viral pathogens and indicators in biosolids-amended soil and studies effect of soil temperature, soil moisture and soil type on persistence (i.e., $\mathrm{T}_{90}$ values) under field- and laboratoryconditions. A review of literature indicates that there have been very few studies which focused on persistence of viruses in biosolids-amended soil. Most of the studies have focused on persistence of enteric viruses in biosolids only but not in soil. Tables 4 and 5 present summary of findings of field- and laboratory-based studies on decay of viruses in biosolids-amended soil. The decay times for viruses in biosolids-amended soil were found to be smaller than 100 days and dependent on factors, such as soil temperature, soil moisture, and soil characteristics. Following sections discuss effects of these factors on decay of viruses. 
Table 4. Summary of findings of laboratory-based studies on persistence of viruses in biosolids-amended soil

\begin{tabular}{lcccc}
\hline $\begin{array}{c}\text { Country/ } \\
\text { Climate }\end{array}$ & Soil Type & $\begin{array}{c}\text { Soil } \\
\text { Temperature } \\
\left({ }^{\circ} \mathrm{C}\right)\end{array}$ & $\begin{array}{c}\text { Virus/ } \\
\text { Indicator }\end{array}$ & $\begin{array}{c}\text { Study Period } \\
\text { (Days) }\end{array}$ \\
\hline
\end{tabular}

\section{Activated Sludge}

\begin{tabular}{|c|c|c|c|c|c|c|}
\hline $\begin{array}{l}\text { Country/ } \\
\text { Climate }\end{array}$ & Soil Type & $\begin{array}{c}\text { Soil } \\
\text { Temperature } \\
\left({ }^{\circ} \mathrm{C}\right)\end{array}$ & $\begin{array}{c}\text { Virus/ } \\
\text { Indicator }\end{array}$ & $\begin{array}{c}\text { Study Period } \\
\text { (Days) }\end{array}$ & $T_{90}$ (Days) & References \\
\hline \multirow{4}{*}{$\begin{array}{l}\text { Israel } \\
\text { Subtropical } \\
\text { climate }\end{array}$} & \multirow{4}{*}{$\begin{array}{l}\text { Loess soil ( } 65 \% \\
\text { sand, } 10 \% \text { silt, } \\
\text { and } 25 \% \text { clay) }\end{array}$} & 15 & Cox A9 & 21 & 3.5 & \multirow{4}{*}{$\begin{array}{l}\text { Nasser et } \\
\text { al., } 2002\end{array}$} \\
\hline & & 30 & Cox A9 & 21 & 1 & \\
\hline & & 15 & MS2 & 21 & 10.5 & \\
\hline & & 30 & MS2 & 21 & 1.5 & \\
\hline
\end{tabular}

Anaerobically-digested Sludge

$\begin{array}{lllcccr} & \text { Clay loam } & 15 & \text { Poliovirus } & 28 & 16^{\text {a }} & \\ \text { USA, } & \text { Sandy soil } & 15 & \text { Poliovirus } & 28 & 11^{\text {a }} & 3^{\text {a }} \\ \text { Arizona } & \text { Clay loam } & 15 & \text { MS2 } & 28 & 3^{\text {a }} & \text { Straub et } \\ \begin{array}{l}\text { Desert } \\ \text { climate }\end{array} & \text { Sandy soil } & 15 & \text { MS2 } & 28 & 5^{\text {a }} \\ & \text { Clay loam } & 40 & \text { PRD1 } & 7 & 4^{\text {a }}\end{array}$

${ }^{\mathrm{a}} \mathrm{T}_{90}$ values calculated from model described in methodology

Table 5. Data from a field-based study (Schwarz et al., 2013) on persistence of viruses in anaerobically -digested biosolids-amended soil Moora, Western Australia; Climate=Temperate; soil type=not mentioned; Soil moisture $=35$ to $40 \%$; temperature $=35$ to $40^{\circ} \mathrm{C}$; exposure time period $=7$ months

\begin{tabular}{lcc}
\hline \multicolumn{1}{c}{ Soil/biosolids } & Virus & T $_{\mathbf{9 0} \text { v }}$ alue (Days) \\
\hline Unamended soil & MS2 & 29 to108 \\
Biosolids-amended soil & MS2 & 22 to 36 \\
Unamended soil & Adenovirus & $>180$ \\
Biosolids-amended soil & Adenovirus & $>180$
\end{tabular}

\subsection{Soil temperature and soil moisture content}

This section documents effect of soil temperature and soil moisture content on persistence of biosolids-associated viruses and viral indicators in biosolids-amended soil. Desiccation and temperature have been shown to affect decay of viruses in soil. For example, a study reported that poliovirus or echovirus was not detected in soil after 8 days in fall condition whereas these viruses were found to survive for 35 days in wet summer $(13.6 \mathrm{~cm}$ rainfall, temperature: $23.5-29^{\circ} \mathrm{C}$; Bitton et al., 1984). Another study reported that poliovirus could survive up to 170 days at temperature of $3-10^{\circ} \mathrm{C}$ (Bagdasaryan, 1964). The viral indicator, MS2, was found to decay more in dry conditions than in humid conditions $\left(-3.3-25^{\circ} \mathrm{C}\right.$; Choi et al., 2004). $\mathrm{T}_{90}$ of adenovirus- 2 was observed to be 35 days at $20^{\circ} \mathrm{C}$ and 132 days at $4^{\circ} \mathrm{C}$ (Ogorzaly et al., 2010). Cox A9 of activated sludge -based biosolids was observed to survive more at $15^{\circ} \mathrm{C}\left(\mathrm{T}_{90}=3.5\right.$ days $)$ than at $30^{\circ} \mathrm{C}\left(\mathrm{T}_{90}=1\right.$ days $)$ on loess soil (65\% sand, $10 \%$ silt, and $25 \%$ clay) (Nasser et al., 2002) (Table 4). Similar type of trend was observed for MS2 (Nasser et al., 2002) (Table 4). Some studies have also reported the effect of different depths of soil on $\mathrm{T}_{90}$ values of viruses. For example, $\mathrm{T}_{90}$ values were observed to vary from 1 to 30 days (in soil samples collected from $0-5 \mathrm{~cm}$ depth) and from 12 to 56 days (in soil samples collected from $5-15 \mathrm{~cm}$ depth) (minimum $\mathrm{T}_{90}$ value=1 day (hot summer); 56 days (winter)) (Sorber and Moore, 1987). In a microcosm study, $\mathrm{T}_{90}$ values of decay of AdV-GFP and MNV-1 in sediment were found to be 7.49 and 6.4 days, respectively under natural condition and 27.4 and 18.6days, respectively in dark condition (Elmahdy et al., 2018). More inactivation of viruses in sediment was observed under sunlight and high temperature conditions. 


\subsection{Soil type}

This section documents effect of soil type and soil conditions on persistence of biosolids-associated viruses and viral indicators in biosolids-amended soil. Adsorption of viruses to soil has been observed to decrease their decay rate in soil. Factors, such as soil pH, soil characteristics (clay content, exchangeable phosphorous, exchangeable aluminium content) affect decay of viruses in biosolidsamended soil (Hurst et al., 1980). Soil pH has been shown to affect adsorption of viruses on soil. Low soil pH increases adsorption of viruses on soil and thus it decreases their numbers in soil. An increase in soil pH has been shown to increase virus decay rate, i.e., decrease in virus survival (Hurst et al.,1980). Clayey soil has been shown to increase virus adsorption as compared to sandy soil (Straub et al., 1992) and thus, virus survive more in sandy soil than in clayey soil. For example, two virus types (PhiX-174, vMC) were observed to survive more in sandy soil than in clayey soil (Fongaro et al., 2017). $\mathrm{T}_{90}$ values of Phix-174 were observed to be $10.5 \pm 0.6$ days in clayey soil than $21.2 \pm$ 1.1 days in sandy soil. Similarly, $\mathrm{T}_{90}$ values of $\mathrm{vMC}_{0}$ were observed to be $12.4 \pm 1.3$ days in clayey soil than $43.4 \pm$ 1.3 days in sandy soil (Fongaro et al., 2017). Poliovirus of anaerobically-digested sludge was observed to survive more in clayey loam soil $\left(\mathrm{T}_{90}=16\right.$ days $)$ than in sandy soil $\left(\mathrm{T}_{90}=11\right.$ days) (temperature $=150^{\circ} \mathrm{C}$; desert climate) (Straub et al., 1992; Table 4). Further, virus number concentration has been observed to decrease more in unamended soil than in biosolids-amended soil. For example, a field-based study (Schwarz et al., 2013) reported that both MS2 and adenovirus survived more in unamended soil than in biosolids-amended soil (Table 5). These observations indicate that soil type affects survival of viruses and need to be considered for deciding setback time for minimizing contact of humans with virus particles from biosolidsamended soil.

\subsection{Persistence of protozoa in biosolids- amended soil}

This section documents effect of soil temperature and soil moisture content on persistence of biosolids-associated protozoa in biosolids-amended soil using information from small number of available studies. Not much research has been carried out for understanding persistence of protozoa, such as Giardia and Cryptosporidium spp. in biosolidsamended soil. Data related to decay of protozoa in actual field conditions have been lacking and studies have used laboratory conditions for studying decay patterns of protozoa in biosolids-amended soil. For example, sentinel chambers replicating soil environmental conditions were used to study survival of oocysts (Jenkins et al., 1999). Factor, such as temperature, $\mathrm{pH}$, and ammonia had been found to affect inactivation of oocysts. A decline of oocysts has been reported for temperature ranging between $35^{\circ} \mathrm{C}$ and $50^{\circ} \mathrm{C}$ within 70 days. High temperature was observed to affect inactivation rate of protozoan cysts, making them less resistant to heat than other pathogens (Pepper et al., 2006). Decay of Cryptosporidium parvum in biosolidsamended soil was observed to increase with high temperature and soil desiccation (Nasser et al., 2007). Overall, a review of small number of available studies indicated that temperature affects inactivation of occysts. However, effect of other factors on inactivation of protozoa has not be studied in details. More efforts in this direction is required so that a complete understanding on decay of biosolids-associated protozoa in biosolids-amended soil can be developed.

\subsection{Persistence of helminths in biosolids- amended soil}

This section documents effect of soil temperature and soil type on persistence of helminths in biosolids-amended soil using information from small number of available studies. Helminths, such as Ascaris lumbricoides, Trichuris trichiura, Taenia saginata, Taenia solium, Necator americanus, and Hymenolepsis nana are also present in biosolids and may pose exposure risks to human after land application activities. Tables 6 and 7 present summary of findings of field- and laboratory-based studies on decay of Ascaris in biosolids-amended soil, respectively. Ascaris eggs have been used as an indicator for Helminths ova and have been mostly studied. Survival of helminths ova has been observed to be dependent on soil temperature, soil type and soil conditions (Maya et al., 2010; de Faria et al., 2017). Following sections present relation of different factors on persistence of helminths in biosolids-amended soil.

Table 6. Summary of findings on field-based study on persistence of Ascaris in anaerobically-digested biosolids-amended soil

\begin{tabular}{|c|c|c|c|c|c|c|}
\hline $\begin{array}{c}\text { Country /Climate } \\
\text { Region }\end{array}$ & Soil Type & Application Type & Experimental Condition & $\begin{array}{l}\text { Study } \\
\text { Period } \\
\text { (Days) }\end{array}$ & $T_{90}$ (Days) & References \\
\hline $\begin{array}{l}\text { Brazil, Tropical } \\
\text { climate }\end{array}$ & $\begin{array}{c}\text { Sandy soil; } \\
\text { w/ } \\
\text { Eucalyptus }\end{array}$ & $\begin{array}{c}\text { Injection; rate }=40 \\
\text { t/ha }\end{array}$ & $\begin{array}{l}\text { temperature }= \\
15 \text { to } 30^{\circ} \mathrm{C} \text {; soil } \\
\text { moisture }=80 \%\end{array}$ & 364 days & $49^{\mathrm{a}}$ & $\begin{array}{l}\text { de Faria et } \\
\text { al., } 2017\end{array}$ \\
\hline
\end{tabular}


Table 7. Summary of findings of a laboratory-based study (Williams et al., 2012) on persistence of Ascaris spp. in dewatered, mesophilic, anaerobically digested sludge biosolids-amended soil Tucson, Arizona (USA); Hot semi-arid climate; Application type $=$ Soil-biosolids mixture; temperature $=2.8$ to $34.3^{\circ} \mathrm{C}$; exposure time $=30$ days

\begin{tabular}{lcc}
\hline & Soil Type & T $_{\mathbf{9 0}}$ (Days) \\
\hline Sandy loam & 15 & 19 \\
clayey soil & & 19
\end{tabular}

\subsection{Soil temperature}

This section documents effect of soil temperature on persistence of helminths in biosolids-amended soil. Effect of climate on survival of helminths has been studied extensively. In temperate climate regions, ova have been found to remain viable for up to 7 years in the soil (Smith et al., 1999), indicating a chance of exposure long after the application of biosolids on soil. Average time for persistence of viable Ascaris spp. ova in biosolids-amended soil was observed to be about 7 weeks under humid temperature $\left(70 \%\right.$ moisture, $20^{\circ} \mathrm{C}$, conventional aerobically -digested activated sludge; de Faria et al., 2017). Two Brazilian studies (Thomaz-Soccol et al. (1999) and Souza et al. (2008) reported that helminths ova survived longer for 180 days in biosolids-amended soil in colder region than 3 weeks in other studied regions of Brazil.

\subsection{Soil type}

This section documents effect of soil type on persistence of helminths in biosolids-amended soil. Effect of soil type on survival of Ascaris ova has also been reported. Ova incubated in biosolids- amended clay loam was observed to survive more than ova incubated in sandy loam (Williams et al., 2012). For example, Ascaris spp. of dewatered, mesophilic, anaerobically digested sludge was observed to survive longer in clayey soil $\left(\mathrm{T}_{90}=19\right.$ days $)$ than in sandy loam soil ( $\mathrm{T}_{90}=15$ days) (Williams et al., 2012; Table 7). For temperature ranging between 20 and $38^{\circ} \mathrm{C}$, survival times for Ascaris in clay soil were observed to be greater than 90 days due to higher retention of moisture by clayey particles. Ova incubated at $25^{\circ} \mathrm{C}$ was observed to have a lower inactivation rate than that at $37^{\circ} \mathrm{C}$. Temperatures above $50^{\circ} \mathrm{C}$ had been shown to shorten the inactivation duration of Ascaris to 2 hours (Kato et al., 2003).

\subsection{Identified knowledge gaps and recommendations for future studies}

A compilation of information related to decay of biosolids-associated indicator microorganisms and pathogens in soil was carried out with an emphasis of use of field-related information and some laboratory-related information. A general trend of decay of biosolidsassociated bacteria and viruses in biosolids-amended soil with respect to soil temperature, soil moisture content, soil type, organic matter is shown in Figures 4 and 5, respectively. These figures represent the probable trends of decay of BAPs in different environmental conditions as observed from the studies reported. An exact trend of pathogen decay with environmental factors cannot be developed from little data available for some of the pathogens. A comparison of variations of T90 with temperature for tropical and temperate climatic regions indicated that T90 values decrease with temperature (Figure 4). Viruses also show similar type of trend in all climatic conditions. In case of bacterial pathogens, variation of T90 with moisture content was observed to vary between two climatic conditions. T90 value was observed to be high at high moisture content for tropical condition and low for temperate condition (Figure 5). The variation of decay behaviour under different climatic conditions also depend on other factors, like biotic stress, organic matter content, time period, etc. (Figures 4 and 5). 3D scatterplot has been shown to show effect of temperature and moisture content on persistence of $\mathrm{E}$. coli (bacteria), MS2 (Virus), Ascaris (Helminth) (Figure 6). This plot (Figure 6) shows persistence of bacteria is longer than virus and helminth in given temperature and moisture condition keeping soil and biosolid same. Similar types of plots in different environmental condition (Temperature, moisture, soil type, biosolids type) would help in understanding factors affecting persistence in better way. 
(a)

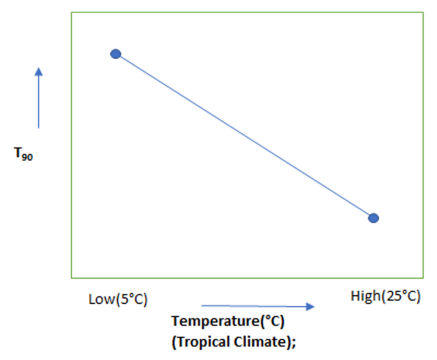

(b)

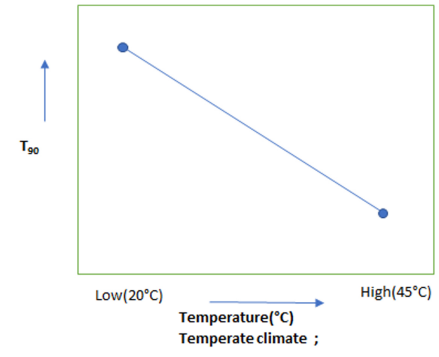

(c)

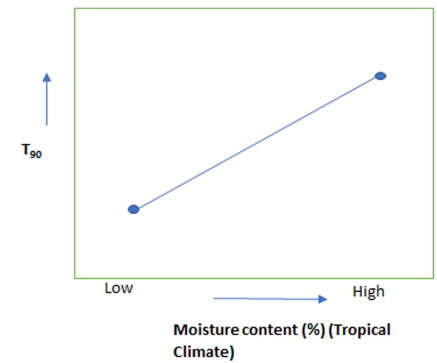

(e)
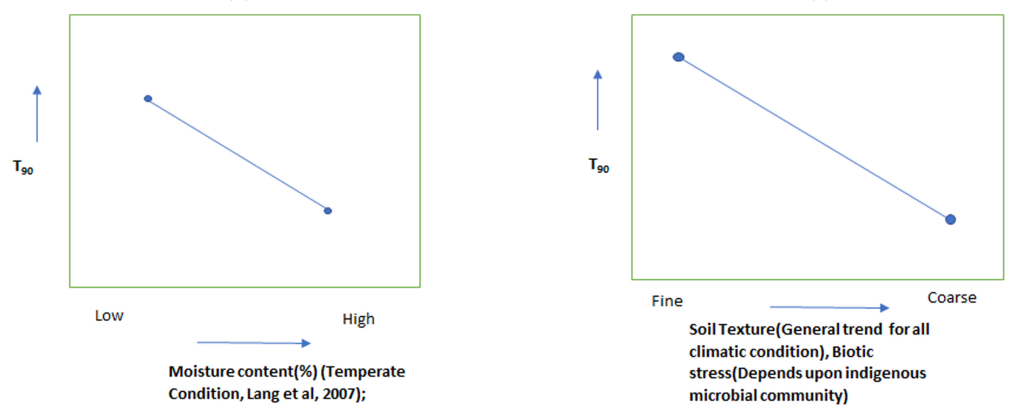

Figure 4. General trends showing effect on decay of biosolids-associated bacteria (shown in terms of $T_{90}$ ) due to: (a and b) temperature; (c and d) moisture content, (e) soil texture, biotic stress

(a)

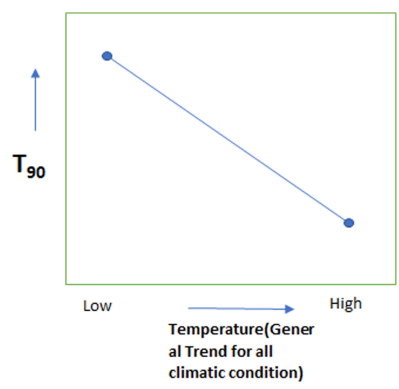

(b)

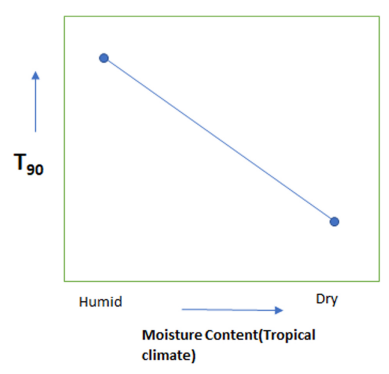

(c)

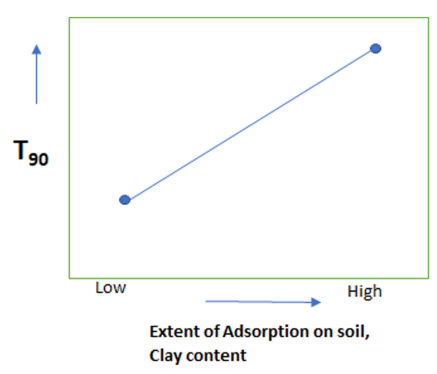

Figure 5. General trends showing effect on decay of biosolids-associated viruses (shown in terms of $T_{90}$ ) due to: (a) temperature; (b) moisture content, (c) extent of adsorption on soil or clay content

3D Scatterplot of T90(Days) vs Moisture Content(\%) vs Temperature(C)

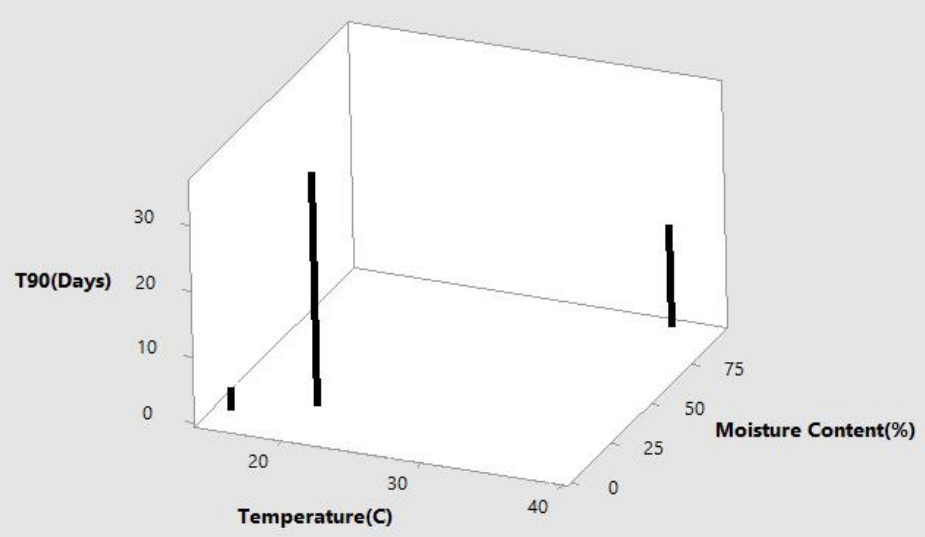

Figure 6. Effect of persistence of biosolids-associated pathogens (E. coli, MS2, and Ascaris) as a function of temperature and moisture content in sandy soil amended with anaerobic digested sludge 
Table 8 presents a list of field-related important identified knowledge gaps which need to be addressed immediately. More fields -related studies are required for obtaining these types of information to make decisions using realistic field-based information with respect to biosolids application on soil.

Table 8. Identified knowledge gaps and possible recommended actions

\begin{tabular}{|c|c|}
\hline Gap Type & Impact of Identified Gaps \\
\hline $\begin{array}{l}\text { Combined effect of } \\
\text { different factors on } \\
\text { pathogen survival }\end{array}$ & $\begin{array}{c}\text { Factors (i.e., soil pH, temperature, moisture content, biotic stress, } \\
\text { competition for nutrients, etc.), interact with amongst each other } \\
\text { and affect pathogen survival; findings of studies focusing on one } \\
\text { factor-at-a-time do not provide complete information on survival } \\
\text { when multiple factors simultaneously affect pathogen survival; } \\
\text { information is useful in determining decay rate under different } \\
\text { environmental condition (Simultaneous effect of temperature, } \\
\text { moisture content, soil type, etc.) }\end{array}$ \\
\hline $\begin{array}{l}\text { Decay patterns of } \\
\text { viruses helminth, } \\
\text { protozoa in biosolids- } \\
\text { amended soil }\end{array}$ & $\begin{array}{l}\text { Studies are available on decay behaviours of bacteria in biosolids- } \\
\text { amended soil, but this type of information is not available } \\
\text { extensively for viruses and protozoa. As biosolids carry both viruses } \\
\text { and protozoa, chances of their exposures from biosolids-amended } \\
\text { soil exist; information is useful in deciding setback distance and } \\
\text { setback time using decay patterns information of all types of BAPs } \\
\text { as } \mathrm{T}_{90} \text { values of different BAPs vary widely }\end{array}$ \\
\hline $\begin{array}{l}\text { Decay patterns based } \\
\text { on field-related data }\end{array}$ & $\begin{array}{l}\text { Information on decay rates for enteric pathogens in biosolids - } \\
\text { amended soil is valuable more under laboratory conditions than } \\
\text { under field conditions. Field studies present monitoring challenges } \\
\text { as soil has varied physiochemical properties which could affect } \\
\text { decay of pathogens differently; } \mathrm{T}_{90} \text { values obtained from field-related } \\
\text { studies can be used for framing land application of biosolids } \\
\text { guidelines }\end{array}$ \\
\hline
\end{tabular}

\section{Possible Actions (References)}

Conduct more field studies

(Lang et al.,2007;

Cass,2009; Gondim-Porto et al., 2017)

Conduct more decay studies for different types of pathogens

(Jenkins et al.,1999;

Schwarz et al., 2013; de

Faria et al.,2017)

Conduct more field-related studies

(Pepper et al.,1993; Gibbs et al., 1997; Lang et al., 2003; Lang et al., 2007;Zaleski et al., 2005; Eamens et al., 2006; Pourcher et al., 2007; Horswell et al., 2007; Elmahdy et al.,2018)

${ }^{a}$ BAP-biosolids associated pathogens

\section{Acknowledgements}

The authors would like to thank Indian Institute of Technology Delhi (India), Drexel University Philadelphia
(USA), the Ohio State University (USA) and Temple University (USA) for providing financial supports for this work. 


\section{References}

Bagdasaryan, G.A. and,. (1964). Survival of Viruses of the Enterovirus Group (Poliomyelitis, ECHO, Coxsackie) in Soil and on Vegetables. Journal of Hygiene, Epidemiology, Microbiology and Immunology. 8, Prague. pp. 497-505.

Bitton, G., Pancorbo, O.C. and,. (1984). Virus transport and survival after land application of sewage sludge. Applied and Environmental Microbiology. 47, Am Soc Microbiol. pp. 905-909.

Burge, W.D., Enkiri, N.K. and Hussong, D. (1987). Salmonella regrowth in compost as influenced by substrate (Salmonella regrowth in compost). Microbial Ecology. 14, Springer. pp. 243-253.

Cass, J. (2009). Field and laboratory investigations quantifying the factors responsible for enteric pathogen decay in biosolids amended agricultural soils. Imperial College London.

Chandler, D.S. and Craven, J.A. (1980). Relationship of soil moisture to survival of Escherichia coli and Salmonella typhimurium in soils. Australian Journal of Agricultural Research. 31, CSIRO. pp. 547-555.

Choi, C., Song, I., Stine, S., Pimentel, J. and Gerba, C. (2004). Role of irrigation and wastewater reuse: comparison of subsurface irrigation and furrow irrigation. Water Science and Technology. 50, IWA Publishing. pp. 61-68.

de Faria, M.F., Guerrini, I.A., Oliveira, F.C., Sato, M.Inês Z., Hachich, E.M., Passos, J.Raimundo S. et al. (2017). Persistence of Ascaris spp. Ova in Tropical Soil Cultivated with Eucalyptus and Fertilized with Municipal Biosolids. Journal of Environmental Quality. 46, The American Society of Agronomy, Crop Science Society of America, and Soil Science Society of America, Inc. pp. 522-527.

Eamens, G.J., Waldron, A.M. and Nicholls, P.J. (2006). Survival of pathogenic and indicator bacteria in biosolids applied to agricultural land. Soil Research. 44, CSIRO. pp. 647-659.

Eisenberg, J.N.S., Moore, K., Soller, J.A., Eisenberg, D. and Jr, J.M.Colford (2008). Microbial risk assessment framework for exposure to amended sludge projects. Environmental Health Perspectives. 116, National Institute of Environmental Health Science. pp. 727.

Elmahdy, M.E.I., Magri, M.E., Garcia, L.A., Fongaro, G. and Barardi, C.R.M. (2018). Microcosm environment models for studying the stability of adenovirus and murine norovirus in water and sediment. International Journal of Hygiene and Environmental Health. Elsevier.

EPA, U.S. (1998). Environmental impacts of animal feeding operations.

Estrada, I.B., Aller, A., Aller, F., Gomez, X. and Moran, A. (2004). The survival of Escherichia coli, faecal coliforms and enterobacteriaceae in general in soil treated with sludge from wastewater treatment plants. Bioresource Technology. 93, Elsevier. pp. 191-198.

Fongaro, G., García-González, M.C., Hernández, M., Kunz, A., Barardi, C.R.M. and Rodríguez-Lázaro, D. (2017). Different behavior of enteric bacteria and viruses in clay and sandy soils after biofertilization with swine digestate. Frontiers in Microbiology. 8, Frontiers. pp. 74. 
Gale, P. (2005). Land application of treated sewage sludge: quantifying pathogen risks from consumption of crops. Journal of Applied Microbiology. 98, Wiley Online Library. pp. 380-396.

Gerba, C.P. and Smith, J.E. (2005). Sources of pathogenic microorganisms and their fate during land application of wastes. Journal of Environmental Quality. 34, American Society of Agronomy, Crop Science Society of America, Soil Science Society. pp. $42-48$.

Gibbs, R.A., Hu, C.J., Ho, G.E. and Unkovich, I. (1997). Regrowth of faecal coliforms and salmonellae in stored biosolids and soil amended with biosolids. Water Science and Technology. 35, pp. 269 - 275. doi: https://doi.org/10.1016/S0273-1223(97)00271-0.

Gibbs, R.A., Hu, C.J., Ho, G.E. and Unkovich, I. (1997). Regrowth of faecal coliforms and salmonellae in stored biosolids and soil amended with biosolids. Water Science and Technology. 35, IWA Publishing. pp. 269-275.

Gondim-Porto, C., Platero, L., Nadal, I. and Navarro-Garcia, F. (2016). Fate of classical faecal bacterial markers and ampicillin-resistant bacteria in agricultural soils under Mediterranean climate after urban sludge amendment. Science of the Total EnvironmentScience of the Total Environment. 565, pp. 200-210.

Gurian, P.L., Galada, H., Joe, A., Kumar, A., Olson, B., Olson, M.S. et al. (2012). Site Specific Risk Assessment Tools for Land Applied Biosolids. Water Environment Research Foundation. Water Environment Research Foundation.

GWPP (2018). Global Water Pathogens Project.

Horswell, J., Ambrose, V., Clucas, L., Leckie, A., Clinton, P. and Speir, T.W. (2007). Survival of Escherichia coli and Salmonella spp. after application of sewage sludge to a Pinus radiata forest. Journal of Applied Microbiology. 103, Wiley Online Library. pp. 1321-1331.

Hurst, C.J., Gerba, C.P. and Cech, I. (1980). Effects of environmental variables and soil characteristics on virus survival in soil. Applied and Environmental Microbiology. 40, Am Soc Microbiol. pp. 1067-1079.

Jenkins, M.B., Walker, M.J., Bowman, D.D., Anthony, L.C. and Ghiorse, W.C. (1992). Use of a sentinel system for field measurements ofcryptosporidium parvum oocyst inactivation in soil and animal waste. Applied and Environmental Microbiology. 65(5), pp. 1998-2005.

Kato, S., Fogarty, E. and Bowman, D. (2003). Effect of aerobic and anaerobic digestion on the viability of Cryptosporidium parvum oocysts and Ascaris suum eggs. International Journal of Environmental Health Research. 13, Taylor \&amp; Francis. pp. 169-179.

Lang, N.L., Bellett-Travers, M.D. and Smith, S.R. (2007). Field investigations on the survival of Escherichia coli and presence of other enteric micro-organisms in biosolids-amended agricultural soil. Journal of Applied Microbiology. 103, Wiley Online Library. pp. 1868-1882.

Lang, N.L. and Smith, S.R. (2007). Influence of soil type, moisture content and biosolids application on the fate of Escherichia coli in agricultural soil under controlled laboratory conditions. Journal of Applied Microbiology. 103, Wiley Online Library. pp. 2122-2131. 
Lang, N.L., Smith, S.R., Bellett-Travers, D.M., Pike, E.B. and Rowlands, C.L. (2003). Decay of Escherichia coli in soil following the application of biosolids to agricultural land. Water and Environment Journal. 17,

Wiley Online Library. pp. 23-28.

Lewis, D.L. and Gattie, D.K. (2003). Comment on Evidence for the Absence of Staphylococcus aureus in the Land Applied Biosolids. Environmental Science and Technology. 37, ACS Publications. pp. 5835-5835.

Lu, Q., He, Z.L. and Stoffella, P.J. (2012). Land application of biosolids in the USA: a review. Applied and Environmental Soil Science. 2012, Hindawi.

Mallory, L.M., Yuk, C.S., Liang, L.N. and Alexander, M. (1983). Alternative prey: a mechanism for elimination of bacterial species by protozoa. Applied and Environmental Microbiology. 46, American Society for Microbiology Journals. pp. 1073-1079.

Maya, C., Ortiz, M. and Jimenez, B. (2010). Viability of Ascaris and other helminth genera non larval eggs in different conditions of temperature, lime (pH) and humidity. Water Sci Technol. 62, pp. 2616-24.

Nasser, A.M., Tweto, E. and Nitzan, Y. (2007). Die-off of Cryptosporidium parvum in soil and wastewater effluents. Journal of Applied Microbiology. 102, Wiley Online Library. pp. 169-176.

Nasser, A.M., Tweto, E. and Nitzan, Y. (2002). Contribution of microbial activity to virus reduction in saturated soil. Water Research.

Ngole, V., Mpuchane, S. and Totolo, O. (2006). Survival of faecal coliforms in four different types of sludge-amended soils in Botswana. European Journal of Soil Biology. 42, pp. 208 - 218. doi: https://doi.org/10.1016/j.ejsobi.2006.03.004.

Ogorzaly, L., Bertrand, I., Paris, M., Maul, A. and Gantzer, C. (2010). Occurrence, Survival, and Persistence of Human Adenoviruses and F-Specific RNA Phages in Raw Groundwater. Applied and Environmental Microbiology. 76, American Society for Microbiology Journals. pp. 8019-8025. doi: 10.1128/AEM.00917-10.

Pepper, I.L., Brooks, J.P. and Gerba, C.P. (2006). Pathogens in Biosolids. Advances in Agronomy. 90, Academic Press. pp. 1 - 41. doi: https://doi.org/10.1016/S0065-2113(06)90001-7.

Pepper, I.L., Josephson, K.L., Bailey, R.L., Burr, M.D. and Gerba, C.P. (1993). Survival of indicator organisms in Sonoran Desert soil amended with sewage sludge. Journal of Environmental Science and Health. Part A: Environmental Science and Engineering and Toxicology. 28, Taylor \&amp; Francis. pp. 1287-1302. doi: 10.1080/10934529309375943.

Pourcher, A.M., Françoise, P.-.B., Virginie, F., Agnieszka, G., Vasilica, S. and Gérard, M. (2007). Survival of faecal indicators and enteroviruses in soil after land-spreading of municipal sewage sludge. Applied Soil Ecology. 35,

Elsevier. pp. 473-479.

Roberts, B.N., Bailey, R.H., McLaughlin, M.R. and Brooks, J.P. (2016). Decay rates of zoonotic pathogens and viral surrogates in soils amended with biosolids and manures and comparison of qpcr and culture derived rates. Science of the Total Environment. pp. 671-679. 
Rogers, M. and Smith, S.R. (2007). Ecological impact of application of wastewater biosolids to agricultural soil. Water and Environment Journal. 21, Wiley Online Library. pp. 34-40.

Roper, M.M. and Marshall, K.C. (1977). Effects of a clay mineral on microbial predation and parasitism ofEscherichia coli. Microbial Ecology. 4, pp. 279-289. doi: 10.1007/BF02013272.

Schwarz, K., Sidhu, J., Pritchard, D., Toze, S. and Li, Y. (2010). Decay of Escherichia coli in biosolids applied to agricultural soil. Biosolids Specialty Conference V. Australian Water Association.

Schwarz, K., Toze, S., Pritchard, D., Sidhu, J. and Li, Y. (2013). Decay of human enteric pathogens in agricultural soil amended with biosolids: Key findings from a comprehensive research project to examine potential health risks. Journal of the Australian Water Association. 40, Australian Water Association. pp. 2-6.

Sessitsch, A., Weilharter, A., Gerzabek, M.H., Kirchmann, H. and Kandeler, E. (2001). Microbial Population Structures in Soil Particle Size Fractions of a Long-Term Fertilizer Field Experiment. Applied and Environmental Microbiology. 67, American Society for Microbiology Journals. pp. 4215-4224. doi: 10.1128/AEM.67.9.4215-4224.2001.

Sidhu, J.P. and Toze, S.G. (2009). Human pathogens and their indicators in biosolids: a literature review. Environ Int. 35, pp. 187-201.

Smith, H.V., GRIMASON, T.M. and,. (1999). Ascaris lumbricoides. 48, AMERICAN WATER WORKS ASSOCIATION (Denver). pp. 171-180.

Sorber, C.A. and Moore, B.E. (1987). Survival and transport of pathogens in sludge-amended soil: a critical literature review. Survival and transport of pathogens in sludge-amended soil: a critical literature review. EPA. Water Engineering Research Laboratory.

Souza, C.A., Lemainski, J., da Silva, J.Eurpedes and Mazzotti, H.Adorni (2008). Sobrevivência de ovos de helmintos na reciclagem agrcola do lodo de esgoto no distrito federal. Simpósio Internacional de Savana Tropical.

Straub, T.M., Pepper, I.L. and Gerba, C.P. (1992). Persistence of Viruses in Desert Soils Amended with Anaerobically Digested Sewage Sludge. Applied and Environmental Microbiology. 58, American Society for Microbiology Journals. pp. 636-641.

Thomaz-Soccol, V., Paulino, R.C. and Castro, E.A. (1999). Agentes patogênicos: helmintos e protozoários. Reciclagem de biossólidos: transformando problemas em soluções. Curitiba: SANEPAR. pp. 156-174.

Williams, D.L., Pepper, I.L. and Gerba, C.P. (2012). Survival of Ascaris ova in desert soils: A risk assessment. Journal of Residuals Science and Technology. 9, DEStech Publications Inc. pp. 151-157.

$\mathrm{Xu}$, C., Wang, D., Huber, A., Weese, S.J. and Warriner, K. (2016). Persistence of Clostridium difficile in wastewater treatment-derived biosolids during land application or windrow composting. Journal of Applied Microbiology. 120, pp. 312-320.

You, Y., Rankin, S.C., Aceto, H.W., Benson, C.E., Toth, J.Daniel and Dou, Z. (2006). Survival of Salmonella enterica serovar Newport in manure and manure-amended soils. Applied and Environmental Microbiology. 72 9, pp. 5777-83. 
Zaleski, K.J., Josephson, K.L., Gerba, C.P. and Pepper, I.L. (2005). Potential regrowth and recolonization of salmonellae and indicators in biosolids and biosolid-amended soil. Applied and Environmental Microbiology. 71, pp. 3701-3708. 